\title{
Support Bahrain's imprisoned doctors
}

\author{
Fiona Godlee editor, BMJ
}

\begin{abstract}
Many of you will have been following the fate of the 20 Bahraini doctors and other health professionals caught up in the prodemocracy demonstrations in February. After being arrested and in some cases tortured, the doctors were then put through what Amnesty International has called a "sham" trial, and despite international pressure on Bahrain's government, they were last week given "ludicrous" sentences of up to 15 years (doi:10.1136/bmj.d6336). Another 27 health professionals are facing lesser charges and awaiting verdicts.
\end{abstract}

Charged with playing a key role in inciting hatred of the regime, distributing false news, and refusing to treat Sunni patients, the doctors say they have been persecuted for treating wounded anti-government protestors. Most of them worked at Bahrain's only major medical centre, which became the epicentre of the unrest. The doctors deny sectarian bias in treating patients.

News of the sentences has caused outrage among medical and human rights groups. In what Physicians for Human Rights (PHR) calls "the most extreme violations of medical neutrality in the past half century," commentators from around the world agree that the doctors are being punished for doing what international codes of medical ethics require-treating all patients regardless of their political, ethnic, or religious allegiance (doi:10.1136/bmj.d2768). In light of the events in Bahrain, PHR has called on the United Nations Human Rights Council to appoint a special rapporteur on medical neutrality.

The BMA has been among those working to convince Bahrain's government of the need for fair judicial process and respect for medical ethics (http://blogs.bmj.com/bmj/2011/09/20/viviennenathanson-and-eleanor-chrispin-bahrain-on-trial/). In a letter to the Guardian newspaper, Hamish Meldrum, chairman of BMA Council, expresses “in the strongest possible terms [the BMA's] deep concerns" at what he calls a politically motivated trial (www.guardian.co.uk/world/2011/sep/30/deep-concern-overbahrain-medics?INTCMP=SRCH).

But confident in the support of its powerful ally Saudi Arabia, Bahrain has so far felt able to ignore such approaches. And the restrained response from the UK's foreign secretary- "these sentences appear disproportionate"-will have done little to change this. But a recent article in the Economist reminds us of another route (www.economist.com/node/21529019).

"Promoting human rights in thick-skinned countries is not a hopeless cause," it says. "All tyrants want things from the West-from a haven for their ill-gotten gains to recreation for their families. When access to these goodies is withdrawn it can send a powerful signal." The examples it gives are cancellation of fashion shows and rock concerts and withdrawal of banking services.

How can medical professionals send this sort of powerful signal to Bahrain? I don't have an immediate answer, but I'm pleased to report that the BMJ Group has stopped all dealings with the Bahraini government since the uprising in February. You may know of other similar actions, in which case we would like to hear about them. Meanwhile we remain deeply concerned about the Royal College of Surgeons in Ireland's continuing close links with Bahrain's government, as reported by Sophie Arie in May (doi:10.1136/bmj.d3259) and evident on the college's website (www.rcsi.ie/). Unless the college wants to open itself to charges of complicity, the president should clarify his position as a matter of urgency.

Cite this as: BMJ 2011;343:d6417

๑ $\mathrm{BMJ}$ Publishing Group Ltd 2011 